\title{
O índio escritor será que existe?
}

Does the Indian writer exist?

Olívio Jekupé

Era de manhã como de costume e fui verificar meus email de todos os dias e nisso fiquei feliz porque recebi um grande convite, recebi um convite da FLIP (Feira Literária Internacional de Paraty). Aliás uma das feiras de livro mais importante do Brasil e do mundo, e que são convidados escritores do nosso país e de outros Países. E isso me deixou muito feliz, era um sinal de que eu sou até um pouco conhecido no ramo e isso me deixava muito orgulhoso e eu sabia que o Daniel Mundurukue o Yaguare já tinham sido convidados antes pra essa feira e agora eu, que orgulho.

E logo respondi a mensagem e confirmei minha ida sim, e que estava muito feliz pelo convite. Naquele dia meu coração estava tão alegre que nem sabia explicar, mas a emoção era demais, eu sempre tive vontade de ir um dia na feira pra ver como era, mas por falta de oportunidade nunca tinha ido, mas agora ia ser diferente ia como um dos convidados, como escritor e isso ia ser bom porque eu poderia falar sobre a literatura nativa e falar um pouco sobre a importância da literatura escrita pelos povos indígenas. Que aliás uma literatura que eu via que estava crescendo a cada ano, e quando comecei a escrever em 1984 sei como era difícil e não conhecia nenhum escritor com livro publicado, mas tinha a confiança que lutando um dia nossos trabalhos iam crescer. E com o surgimento de outros escritores isso foi acontecendo e posso dizer que a partir dos anos de 2000 isso começou a melhorar.

Já chegando em casa aqui na aldeia onde moro fui logo dizendo pra minha mulher que tinha sido convidado. Vi que ela ficou feliz e disse que queria ir também porque ela ia levar os artesanatos que ela faz pra vender para os turistas, é que essa cidade nos dias de evento se vende muitas coisas, aliás em Paraty tem uma aldeia muito guarani onde os sempre tem gente da aldeia vendendo seus artesanatos.

-Sim, então você vai e vai também o Werá e o Jekupe dois dos meus filhos. Na verdade, sempre gosto de levar algum dos meus filhos pra poder passear e conhecer coisas novas. E quanto ao Werá, nasceu em 2001, era novo mas já era um escritor e tinha assinado um contrato com uma editora, e por isso nos lugares que sou convidado sempre ele está junto pra aprender, mas sempre coloco junto pra falar alguma coisa e sempre o público gosta do que fala. 
Os dias foram passando e eu na minha rotina de sempre mas alegre por esse convite que me deixou feliz demais. E nos dias que passaram logo eu recebi outra mensagem, uma mulher da Flip me manda uns dados pedindo que eu mandasse um pequeno currículo sobre minha vida e logo respondi.

Já no outro dia eles mandaram outra mensagem, dizendo que na data certa um carro viria até a aldeia me buscar e ai envie os dados certo, onde fica a aldeia, o endereço para que ele possa chegar tranquilo.

Nisso os dias foram passando e minha mulher já tinha feito alguns artesanatos pra levar no evento. Fez alguns colares, chocalhos, e arcos e flechas.

Alguns dias depois eu recebi outra mensagem e a mulher que tinha contato comigo sobre o evento me falou que no dia da palestra eu estaria junto com outro escrito, que começaria as 10: oo horas da manhã ao lado do famoso Renato Ramos, fiquei feliz de saber disso porque sabia que era o neto do maior escritor do Brasil, o Graciliano Ramos, autor já falecido há muitos anos, mas que tem seus livros lidos até os dias de hoje e nas escolas sempre estudam suas obras, e pra mim ia ser uma alegria imensa estar ao lado do neto desse homem.

As vezes chegam turistas aqui na aldeia pra conhecer um pouco da aldeia e saber como é o dia a dia de uma comunidade e como sempre eu atendo e nisso aproveitava e contava que tinha sido convidado pra participar da FLIP e sempre eu recebia elogios e principalmente de palestrar ao lado de Renato Ramos.

Com o passar do tempo, um dia antes de ir pra Paraty recebi a informação de que tal motorista me pegaria as 7 horas da manhã na aldeia e que ficasse preparado. E que o motorista sairia de da cidade de Paraty as 24 horas da noite e ia direto até a nossa aldeia. Aí avisei minha mulher pra se preparar, e juntos preparar as roupas dos meninos, o Werá e o Jekupe, os dois que iam juntos. Vi que todos estavam alegres por irem juntos.

De repente acordei, já era o dia seguinte, era 6 horas da manhã, minha mulher preparou o café pois a viagem ia ser longa e preparou uns xipa, um bolinho típico da aldeia. Nisso escuto um barulho de um carro, era o motorista que veio nos buscar.

- O senhor é Olivio Jekupe?

- Sim, é eu mesmo.

- Ah que bom que achei.

Fiquei até com dó do motorista que havia chegado de Paraty, tão longe e logo voltar pra lá de novo. Perguntei se queria descansar um pouco. 
- Não, fique tranquilo, já estou acostumado com viagens longas, faço isso todos os dias quase.

- Ah tá.

Que vida difícil essa, pensei. Imagina chegar de Paraty até aqui ele gastou uns $400 \mathrm{~km}$ e agora voltar logo em seguida. Mas antes de sair oferecemos um café pra ele.

- Obrigado, vou aceitar, disse ele.

Em seguida seguimos o caminho para Paraty, cidade que gosto muito bonita, e uma das mais antigas do Brasil, e aliás sempre vou lá mas vou pra aldeia de Paraty, uma comunidade guarani.

E ao chegar na cidade o dia estava muito gostoso, e fomos direto pra um hotel que já estava agendado minha chegada, e meus filhos pequeno o Jeguaka Mirim e o Jekupe Mirim e minha esposa Maria Kerexu ficaram felizes ao chegar no hotel, logo guardamos as coisas e fomos dar uma volta pela cidade, aproveitar antes que escureça, pois ia descansar um pouco pois no outro dia teria mais tempo pra passear.

No outro dia fomos passear e junto levamos no pescoço um crachá com meu nome e da minha mulher, e no meu nome estava escritor- Olivio Jekupeescritor, e tinha um cartão para jantarmos e no outro papel que recebemos dizia que todos os escritores iam almoçar num restaurante fixo todos os dias e a noite com o cartão que recebemos jantaríamos no restaurante que quisermos. E Nessa manhã fomos passear pela cidade, e chegando no centro turístico vimos os parentes guarani vendendo artesanatos, ficamos felizes, e por coincidência eram parentes da minha mulher que mora na aldeia dessa cidade, conhecida como Paraty mirim. Conversamos bastante com eles, pois havia muitos artesanatos para venderem, e nessa festa literária tinha muita gente, e na verdade vi que sempre tinha alguns comprando. Em seguida saímos e fomos no restaurante onde íamos almoçar, e logo que chegamos no local, um segurança veio falar comigo.

-Pois não.

-Vimos almoçar, falei.

Vi que ele olhou estranho pra mim e perguntou de quem era o crachá.

-É meu.

Achei estranha a pergunta, em seguida ele me disse. 
- O restaurante abre as 12:00 horas,

Como faltava ainda 20 minutos então falei que ia dar uma volta pela praia e depois voltaríamos.

Aí ao passear pelo local encontrei outros guarani passeando pela praia e conversamos um pouco, e contei que vim pra feira literária e que fui convidado pra dar palestra e que seria no outro dia.

Já passado uns 20 minutos depois resolvi voltar de novo pro hotel pra almoçarmos, e logo que chegamos era uma mulher que estava agora, o vigilante saiu e era outra pessoa que estava na entrada da porta. Ela me deu uma olhada e disse:

- Pois não.

- Vim almoçar, falei.

- Aqui é só para os escritores.

- Por isso mesmo que vim almoçar, falei em seguida e logo me respondeu.

- Você não entendeu, aqui é só para os escritores.

Aí falei de novo.

- Por isso é que vim almoçar.

Vi que a mulher ficou brava e fiquei sem entender, nisso mostrei uns tick que mostrava também. Aí ela disse que era em outro restaurante e me indicou outro, e fui no endereço indicado, peguei minha família e fomos até esse restaurante, ao achar já estávamos cansados, sentamos e nisso fiquei com medo e mostrei o tick e falei se poderia almoçar e se ta tudo bem.

- Sim, disse o atendente desse outro restaurante. Fiquei com raiva do acontecido e perguntei para o garçom se estava tudo certo e se não aí dar problema com o tick que íamos pagar, como disse que podia almoçar tranquilo, aí perguntei qual era a comida mais cara do restaurante.

-Então me traga 3 almoços.

Aí almoçamos e depois fomos pro hotel onde estávamos hospedados.

No dia seguinte quando era 9:30 uma mulher da Flip veio até o hotel e veio nos buscar e disse que a palestra seria as 10:00 horas e disse em seguida: 
- Depois que você der a palestra com o Renato Ramos (neto de Graciliano Ramos), vocês vão almoçar no mesmo restaurante de ontem, porque é só lá que almoça todos os escritores da FLIP.

Nisso vi que tinha algo errado e fui logo entender o que tinha acontecido ontem, e logo fui dizendo.

- Lá nós não vamos almoçar não.

E a mulher se assustou com o que falei.

- Mas por que?

- É que ontem eu fui com minha família almoçar nesse restaurante, mas os vigilantes não deixaram nós entrar.

Ao falar isso vi que ela se tremia tudo, ficou muito assustada.

- Na verdade eles não acreditaram que eu sou escritor por isso não nos deixaram entrar. Por isso pode deixar, depois da palestra nós iremos num restaurante simples e compro uns marmitex...

Aí seguimos pra local onde seria a palestra. E fiquei feliz ao conhecer o grande escritor Renato Ramos, vi que era muito simples. Já pensou conhecer o neto de um dos maiores escritores do Brasil.

Ao terminar a palestra ficamos dando autógrafo aos que compraram livros meu e o Renato também, em seguida ele foi almoçar naquele restaurante que não tinha me deixado entrar, eu inventei uma desculpa na hora pro Renato e disse que ia mais tarde, mas na verdade íamos almoçar em outro local.

E em seguida levei minha mulher e os filhos em outro lugar pra almoçar, mas quando já era umas 13:30 da tarde eu resolvi ir de novo nesse mesmo restaurante, resolvi tirar a limpo tudo isso, isso é, resolvi ir só pra ver mais uma vez eles não me deixar entrar e nisso eu ia responder o porquê de não deixar um escritor entrar e que foi convidado pela FLIP.

Logo que fui chegando ao lado do restaurante, vi a mulher vigilante que estava na porta pra receber os escritores que vinham almoçar, e nisso percebi que ela sorriu de longe, até achei estranho, ao chegar mais perto, ela mexeu com a mão e me disse:

- Seja bem vindo senhor Olivio Jekupe. 
Até achei estranho aquela educação toda, e imaginei que a mulher da FLIP já deve ter vindo aqui falar com eles.

E logo que almoçamos, eu e meu filho, ai ao sair a vigilante me disse:

- O senhor desculpa por ontem pois houve um mal entendido, é que a FLIP não tinha trazido a lista dos escritores.

Mas na verdade não era nada disso porque na programação já dizia que os escritores tinham que andar com aquele crachá especial, só que eu estava com um e minha mulher também, só que na verdade eles ficaram desconfiado de nós e não acreditava que existia escritor indígena e talvez pensaram que tínhamos achado ou roubado.

Mas tudo bem, eu sou escritor e tem outros e que virão passar por aqui e espero que eles não sejam tratados como eu fui. 